\title{
The interrelationship of serum 1,25-dihydroxyvitamin $D$, 25-hydroxyvitamin D and 24,25-dihydroxyvitamin D in pregnancy at term: a meta-analysis
}

\author{
Peter D. Papapetrou \\ Second Division of Endocrinology, Alexandra Hospital, Athens, Greece
}

\begin{abstract}
OBJECTIVE: To assess the relationship between circulating $25(\mathrm{OH}) \mathrm{D}, 1,25(\mathrm{OH})_{2} \mathrm{D}$, and $24,25(\mathrm{OH})_{2} \mathrm{D}$ in pregnancy at term, and to test the hypothesis that serum $25(\mathrm{OH}) \mathrm{D}$ and $24,25(\mathrm{OH})_{2} \mathrm{D}$ are repressed by high serum $1,25(\mathrm{OH})_{2} \mathrm{D}$ levels. DESIGN: Twenty studies in pregnant women at term and 14 studies in young non-pregnant women were selected from the electronic literature. From these studies the mean serum concentrations of $25(\mathrm{OH}) \mathrm{D}$, $1,25(\mathrm{OH})_{2} \mathrm{D}$, and $24,25(\mathrm{OH})_{2} \mathrm{D}$ from 26 groups of pregnant and 14 groups of non-pregnant young women were analyzed. The grand mean (mean of the means) of serum $25(\mathrm{OH}) \mathrm{D}$, serum $1,25(\mathrm{OH})_{2} \mathrm{D}$, and of the ratio $1,25(\mathrm{OH})_{2} \mathrm{D} / 25(\mathrm{OH}) \mathrm{D}$ were compared between pregnant and non-pregnant women. Also, the means of serum $1,25(\mathrm{OH})_{2} \mathrm{D}$ were regressed on the means of serum $25(\mathrm{OH}) \mathrm{D}$. The relationship between $25(\mathrm{OH}) \mathrm{D}$ and $24,25(\mathrm{OH})_{2} \mathrm{D}$ was also evaluated using similar methods. RESULTS: The grand mean of $1,25(\mathrm{OH})_{2} \mathrm{D}$ was two-fold higher, and the grand mean of the ratio $1,25(\mathrm{OH})_{2} \mathrm{D} / 25(\mathrm{OH}) \mathrm{D}$ was 2.5 -fold higher in pregnant than in non-pregnant women with comparable serum $25(\mathrm{OH}) \mathrm{D}$. Regression showed no significant relationship between $1,25(\mathrm{OH})_{2} \mathrm{D}$ and $25(\mathrm{OH}) \mathrm{D}$ in pregnant and non-pregnant women. The ratio $24,25(\mathrm{OH})_{2} \mathrm{D} / 25(\mathrm{OH}) \mathrm{D}$ was not different in pregnant and non-pregnanat women. Regression showed significant relationship between $24,25(\mathrm{OH})_{2} \mathrm{D}$ and $25(\mathrm{OH}) \mathrm{D}$ in both pregnant and nonpregnant women. CONCLUSIONS: Serum $1,25(\mathrm{OH})_{2} \mathrm{D}$ is not, whereas serum $24,25(\mathrm{OH})_{2} \mathrm{D}$ is significantly related to serum $25(\mathrm{OH}) \mathrm{D}$ in pregnant women. Serum $24,25(\mathrm{OH})_{2} \mathrm{D}$ seems not to be repressed by the high $1,25(\mathrm{OH})_{2} \mathrm{D}$ levels during pregnancy, whereas a similar conclusion for $25(\mathrm{OH}) \mathrm{D}$ is less clear.
\end{abstract}

Key words: Pregnancy, Vitamin D deficiency, Vitamin D metabolites

Address for correspondence:

Peter D. Papapetrou, M.D., Honorary Director, Second

Division of Endocrinology, Alexandra Hospital.

51 Panagiotou Street, Papagou, 15669, Attica, Greece,

Fax: 21065 37467, e-mail address: pdpap@otenet.gr

Received 06-11-09, Revised 15-02-10, Accepted 01-03-10

\section{INTRODUCTION}

Humans usually obtain more than $80 \%$ of their vitamin $\mathrm{D}_{3}$ from their skin where it is synthesized through the action of ultraviolet sunlight, acquiring the rest from foodstuffs (mainly oily fish or vitamin D fortified food products). The molecule of vitamin D 
$\left(\mathrm{D}_{3}\right.$ or $\left.\mathrm{D}_{2}\right)$ is hydroxylated in the liver and converted to 25-hydroxyvitamin $\mathrm{D}[25(\mathrm{OH}) \mathrm{D}]$, which in turn undergoes a second hydroxylation in the kidney (and many other tissues) resulting in the formation of 1,25dihydroxyvitamin $\mathrm{D}\left[1,25(\mathrm{OH})_{2} \mathrm{D}\right]$, the biologically active metabolite of vitamin $\mathrm{D}$.

The regulation of the production and catabolism of $1,25(\mathrm{OH})_{2} \mathrm{D}$ has recently been reviewed by Plum and DeLuca. ${ }^{1}$ Most, if not all, of the circulating $1,25(\mathrm{OH})_{2} \mathrm{D}$ is produced in the kidney through the action of the enzyme 1- $\alpha$-hydroxylase (CYP27B1) on $25(\mathrm{OH}) \mathrm{D}$. Hypocalcemia activates the secretion of PTH, which acting on the kidney induces the activity of renal 1- $\alpha$-hydroxylase leading to increased circulating levels of $1,25(\mathrm{OH})_{2} \mathrm{D}$. Hypophosphatemia can also activate renal 1- $\alpha$-hydroxylase by an non-clear mechanism, leading also to increased circulating $1,25(\mathrm{OH})_{2} \mathrm{D}$. When both serum calcium and serum phosphorus concentrations are low, renal 1- $\alpha$-hydroxylase is super-stimulated, resulting in extremely high circulating $1,25(\mathrm{OH})_{2} \mathrm{D} .{ }^{1}$ The catabolism of $1,25(\mathrm{OH})_{2} \mathrm{D}$ is also regulated to prevent hypercalcemia and hyperphosphatemia. ${ }^{1}$ The main catabolic enzyme in the vitamin D endocrine system is 24-hydroxylase (CYP24A1). This enzyme attenuates the vitamin responsiveness by catalyzing synthesis of the inactive metabolites $1,24,25(\mathrm{OH})_{3} \mathrm{D}$ and $24,25(\mathrm{OH})_{2} \mathrm{D}$ from $1,25(\mathrm{OH})_{2} \mathrm{D}$ and $25(\mathrm{OH}) \mathrm{D}$, respectively. The high PTH during hypocalcemia not only stimulates the production of $1,25(\mathrm{OH})_{2} \mathrm{D}$ but also decreases its catabolism by decreasing 24-hydroxylase activity, thereby repressing the production of $1,24,25(\mathrm{OH})_{3} \mathrm{D}$ and $24,25(\mathrm{OH})_{2} \mathrm{D}$. Low serum phosphorus decreases the mRNA levels of the 24-hydroxylase to prevent catabolism of $1,25(\mathrm{OH})_{2} \mathrm{D}$. Transcription of the 24hydroxylase gene is stimulated by $1,25(\mathrm{OH})_{2} \mathrm{D}$ and thus $1,25(\mathrm{OH})_{2} \mathrm{D}$ enhances its own catabolism, while PTH has a key control of 24-hydroxylase activity. ${ }^{1}$

The best marker of vitamin D status in the adult is considered to be the 25(OH)D level. Serum concentrations of $25(\mathrm{OH}) \mathrm{D}$ less than $50 \mathrm{nmol} / \mathrm{L}$ characterize vitamin $\mathrm{D}$ insufficiency, and less than $20 \mathrm{nmol} / \mathrm{L}$ severe vitamin D deficiency. The critical $25(\mathrm{OH}) \mathrm{D}$ value of $50 \mathrm{nmol} / \mathrm{L}$ is based on the finding that after treatment of vitamin $\mathrm{D}$ deficient persons with stepwise increased doses of vitamin D, no further suppression of plasma parathyroid hormone $(\mathrm{PTH})$ was noted when serum level of $25(\mathrm{OH}) \mathrm{D}$ surpassed $50 \mathrm{nmol} / \mathrm{L}{ }^{2}$ From another point of view, on using regression of plasma PTH on serum $25(\mathrm{OH}) \mathrm{D}$, it was observed that plasma PTH started to rise when serum $25(\mathrm{OH}) \mathrm{D}$ became lower than $75 \mathrm{nmol} / \mathrm{L}$; thus, serum $25(\mathrm{OH}) \mathrm{D}$ values below this critical level may cause secondary hyperparathyroidism and have been considered to be diagnostic of vitamin D insufficiency. ${ }^{3,4}$ The $25(\mathrm{OH}) \mathrm{D}$ cut-off value of $80 \mathrm{nmol} / \mathrm{L}$ is corroborated by the work of Heany ${ }^{5}$ who found that $25(\mathrm{OH}) \mathrm{D}$ values of $80 \mathrm{nmol} / \mathrm{L}$ or higher are needed for optimal intestinal absorption of calcium. Further validation of the $75 \mathrm{nmol} / \mathrm{L}$ serum concentration as a lower limit of vitamin D sufficiency originated from clinical trials for the treatment of vitamin D deficiency. In several recent trials it was demonstrated that treatment of vitamin D deficient elderly subjects with vitamin D supplements significantly decreased the risk for hip fracture only when $25(\mathrm{OH}) \mathrm{D}$ levels of at least $74 \mathrm{nmol} / \mathrm{L}$ were achieved during therapy. ${ }^{6}$ Finally, Rejmark et $\mathrm{al}^{7}$ demonstrated that in postmenopausal women serum $25(\mathrm{OH}) \mathrm{D}$ is the major determinant of serum levels of $1,25(\mathrm{OH})_{2} \mathrm{D}$; at $25(\mathrm{OH}) \mathrm{D}$ serum levels above $80 \mathrm{nmol} / \mathrm{L}$, serum $1,25(\mathrm{OH})_{2} \mathrm{D}$ do not increase further, whereas below this $25(\mathrm{OH}) \mathrm{D}$ level, serum $1,25(\mathrm{OH})_{2} \mathrm{D}$ decreases progressively with decreasing 25(OH)D levels.

Several longitudinal ${ }^{8-11}$ and cross-sectional ${ }^{12-14}$ studies have shown that, when compared to non-pregnant young women, pregnant women have high serum $1,25(\mathrm{OH})_{2} \mathrm{D}$ concentration from early pregnancy; serum $1,25(\mathrm{OH})_{2} \mathrm{D}$ rises steadily throughout gestation and reaches levels about double those of non-pregnant women at term. The contribution of the placenta to the high circulating $1,25(\mathrm{OH})_{2} \mathrm{D}$ is not clear. Human placenta and decidua can synthesize $1,25(\mathrm{OH})_{2} \mathrm{D}$. Vitamin D receptors (VDR), 1 - $\alpha$-hydroxylase, and 24-hydroxylase are expressed in human placenta and decidua. ${ }^{15}$ Zehnder et $\mathrm{al}^{15}$ demonstrated that the expression of mRNA for 1 - $\alpha$-hydroxylase in decidua was $\sim 1000$-fold higher in the first and second trimester when compared with the third trimester of human pregnancy. In placenta, $1-\alpha$-hydroxylase expression was 80 -fold higher in the first and second when compared with the third trimester biopsies. Therefore, if the placenta were the main source of circulating $1,25(\mathrm{OH})_{2} \mathrm{D}$ one would expect the level of $1,25(\mathrm{OH})_{2} \mathrm{D}$ 
to be higher during early than late stages of pregnancy, unless the catabolism of $1,25(\mathrm{OH})_{2} \mathrm{D}$ during early pregnancy is much higher than in advanced gestation. Thus, it seems more probable that the $1,25(\mathrm{OH})_{2} \mathrm{D}$ in the maternal circulation originates mainly from the maternal kidneys (see also review by Kovacs). ${ }^{16}$ Plasma concentration of vitamin $\mathrm{D}$ binding protein (DBP) is high in pregnancy ${ }^{13}$ and this, at least partly, accounts for the frankly elevated total $1,25(\mathrm{OH})_{2} \mathrm{D}$; free serum $1,25(\mathrm{OH})_{2} \mathrm{D}$ was found to be high ${ }^{13,17}$ or norma ${ }^{18}$ during pregnancy (see ref. 18 for discussion on free serum $1,25(\mathrm{OH})_{2} \mathrm{D}$ in pregnancy).

The high $1,25(\mathrm{OH})_{2} \mathrm{D}$ serum concentration could theoretically induce some changes in the metabolism of vitamin D during human pregnancy. Halloran and Castro $^{19}$ found that chronic $1,25(\mathrm{OH})_{2} \mathrm{D}$ administration in the rat reduced the serum concentration of $25(\mathrm{OH}) \mathrm{D}$ by increasing its metabolic clearance rate (MCR) without affecting its production rate (PR). This treatment also increased both the MCR and PR of $24,25(\mathrm{OH})_{2} \mathrm{D}$. However, the disproportionately larger increase in MCR resulted also in a decrease in the serum concentration of $24,25(\mathrm{OH})_{2} \mathrm{D} .{ }^{19}$ The findings of Berlin and Björkhem were similar. ${ }^{20}$ Clements et $\mathrm{al}^{21}$ showed that in rats the hepatic catabolism of $25(\mathrm{OH}) \mathrm{D}$ is increased by calcium deprivation and that this effect is mediated by $1,25(\mathrm{OH})_{2} \mathrm{D}$ produced in response to secondary hyperparathyroidism. Administration of $1,25(\mathrm{OH})_{2} \mathrm{D}$ in humans significantly decreased serum $25(\mathrm{OH}) \mathrm{D}$ concentration. ${ }^{22}$ Davies et $\mathrm{al}^{23}$ found a significant negative relationship between the elimination half-time $\left(\mathrm{t}^{1} / 2\right)$ of $\left[{ }^{3} \mathrm{H}\right] 25(\mathrm{OH}) \mathrm{D}_{3}$ in serum and serum $1,25(\mathrm{OH})_{2} \mathrm{D}$ concentration in patients with partial gastrectomy and elevated $1,25(\mathrm{OH})_{2} \mathrm{D}$, a finding implying that the endogenous high serum $1,25(\mathrm{OH})_{2} \mathrm{D}$ increased the catabolism of $25(\mathrm{OH}) \mathrm{D}$ in these patients. Clements et $\mathrm{al}^{24}$ showed that the $\mathrm{t}^{1} / 2$ of $\left[{ }^{3} \mathrm{H}\right] 25(\mathrm{OH}) \mathrm{D}_{3}$ in serum was shortened by raising the serum concentration of $1,25(\mathrm{OH})_{2} \mathrm{D}$ in patients with various disorders of bone and mineral metabolism.

The aim of the present meta-analysis was to evaluate the relationship between serum $25(\mathrm{OH}) \mathrm{D}$ and serum $1,25(\mathrm{OH})_{2} \mathrm{D}$ as well as between serum $25(\mathrm{OH}) \mathrm{D}$ and serum $24,25(\mathrm{OH})_{2} \mathrm{D}$ in pregnant women, and also to test the hypothesis that in human pregnancy the high $1,25(\mathrm{OH})_{2} \mathrm{D}$ serum concentration may be causing increased catabolism of $25(\mathrm{OH}) \mathrm{D}$ and thus resulting in relatively low levels of serum 25(OH)D.

\section{METHODS}

The electronic literature (Medline) was searched using the MeSH terms "pregnancy" and "vitamin D" for studies in pregnant women in which measurements of vitamin D metabolites were included. Twenty studies, comprising 26 groups of pregnant women at term, in which at least two of the vitamin D metabolites $25(\mathrm{OH}) \mathrm{D}, 1,25(\mathrm{OH})_{2} \mathrm{D}$, and $24,25(\mathrm{OH})_{2} \mathrm{D}$ were determined, were selected for analysis. The pregnant women of 19 groups did not take vitamin supplements (Table 1A). The women of 7 groups were supplemented with vitamin D (400 IU/d) during their pregnancy (Table 1B). Fourteen control groups of young healthy non-pregnant women, of which 9 were part of the pregnancy studies and 5 were from independent studies, were also analyzed (Table 1C). The means of the parameters from each group of women were analyzed. In the 20 groups of pregnant and 9 groups of non-pregnant women measurements of both $1,25(\mathrm{OH})_{2} \mathrm{D}$ and $25(\mathrm{OH}) \mathrm{D}$ were available and thus the relationship of these two metabolites could be evaluated. In the 13 groups of pregnant and 7 groups of non-pregnant women results of both $25(\mathrm{OH}) \mathrm{D}$ and $24,25(\mathrm{OH})_{2} \mathrm{D}$ were available for a similar analysis.

Comparison between two means by $t$ test and linear regression of the means of a vitamin $\mathrm{D}$ metabolite on the means of a second vitamin D metabolite were performed using GraphPad Prism, GraphPad Software, San Diego, California, USA. Significance was set as a two-tailed $\mathrm{p}<0.05$.

\section{RESULTS}

The mean of the means (grand mean) of serum $25(\mathrm{OH}) \mathrm{D}$, serum $1,25(\mathrm{OH})_{2} \mathrm{D}$, and serum $24,25(\mathrm{OH})_{2} \mathrm{D}$ were not significantly different between vitamin $\mathrm{D}$ supplemented and unsupplemented pregnant women and thus the two categories of pregnant women were combined into a single category.

The relationship between $1,25(\mathrm{OH})_{2} \mathrm{D}$ and $25(\mathrm{OH}) \mathrm{D}$ is shown in Figure 1. The mean of the means (grand mean) of serum $25(\mathrm{OH}) \mathrm{D}$ in pregnant women $(n=20$ means) was not different from the grand mean ( $\mathrm{n}=9$ means) in non-pregnant controls 
Table 1. Serum levels of vitamin D metabolites in groups of pregnant women at term and groups of non-pregnant young women in the various studies

\begin{tabular}{|c|c|c|c|c|c|}
\hline 25(OH)D (nmol/L) & $1,25(\mathrm{OH})_{2} \mathrm{D}(\mathrm{pmol} / \mathrm{L})$ & $24,25(\mathrm{OH})_{2} \mathrm{D}(\mathrm{nmol} / \mathrm{L})$ & Week of pregnancy & Number of women & Reference \\
\hline \multicolumn{6}{|c|}{ A. Pregnant women not taking vitamin D supplements } \\
\hline $41.5 \pm 2.8^{\mathrm{a}}$ & $146.4 \pm 15.4$ & & Term & 36 & 25 \\
\hline $55.3 \pm 6.5$ & $185.1 \pm 25.9$ & & Term & 25 & 26 \\
\hline 21.3 & 240.0 & & $36-40$ & 10 & 12 \\
\hline $33.8 \pm 2.0$ & $232.8 \pm 9.8$ & & Term & 40 & 13 \\
\hline \multirow[t]{2}{*}{$45.0 \pm 5.0$} & $142.0 \pm 12.0$ & $3.0 \pm 0.7$ & 34 & 18 & 27 \\
\hline & $212.7 \pm 23.3$ & $4.9 \pm 0.7$ & Term & 30 & 28 \\
\hline $82.0 \pm 8.3$ & $236.7 \pm 29.5$ & $6.1 \pm 0.7$ & Term & 9 (Jewish) & 29 \\
\hline $37.8 \pm 6.5$ & $200.7 \pm 27.1$ & $1.7 \pm 0.3$ & Term & 12 (Bedouin) & 29 \\
\hline $44.5 \pm 3.9$ & $207.7 \pm 16.8$ & $4.8 \pm 0.6$ & Term & $32^{\mathrm{b}}$ & 14 \\
\hline $26.0 \pm 2.3$ & $200.0 \pm 21.9$ & $3.6 \pm 0.4$ & Term & $36^{\mathrm{c}}$ & 14 \\
\hline $9.4 \pm 0.9$ & $66.1 \pm 2.6$ & & Term & 29 & 30 \\
\hline $45.1 \pm 5.3$ & $86.4 \pm 10.1$ & $3.7 \pm 0.8$ & $37-40$ & 26 & 31 \\
\hline $42.3 \pm 3.5$ & & $2.7 \pm 0.3$ & Term & $45^{\mathrm{d}}$ & 32 \\
\hline $64.5 \pm 5.3$ & & $6.2 \pm 0.5$ & Term & $33^{\mathrm{e}}$ & 32 \\
\hline 15.1 & 150.0 & & Term & 30 (Pakistani) & 33 \\
\hline 43.1 & 137.5 & & Term & 23 (Norwegian) & 33 \\
\hline $35.0 \pm 1.7$ & $333.0 \pm 13.4$ & & Term & 40 & 9 \\
\hline $117.5 \pm 12.5$ & $242.4 \pm 14.4$ & & $32-35$ & 23 & 34 \\
\hline $52.0 \pm 6.7$ & $212.0 \pm 22.2$ & & $34-36$ & 14 & 10 \\
\hline
\end{tabular}

\section{B. Pregnant women supplemented with vitamin D $(400 \mathrm{IU} / \mathrm{d})^{\mathrm{f}}$}

\begin{tabular}{cccccc}
$37.8 \pm 5.5$ & $3.8 \pm 0.5$ & Term & 10 (black) & 35 \\
$50.0 \pm 4.9$ & $5.8 \pm 0.8$ & Term & 13 (white) & 35 \\
$40.8 \pm 3.3$ & $2.0 \pm 0.3$ & $31-40$ & 25 & 36 \\
$76.9 \pm 11.2$ & $216.3 \pm 23.7$ & & Term & 10 & 37 \\
$69.5 \pm 5.4$ & $196.8 \pm 12.2$ & & $3^{\text {rd }}$ trim. & 17 & 17 \\
$45.5 \pm 9.6$ & $155.8 \pm 12.9$ & $2.5 \pm 0.5$ & Term & 10 (black) & 38 \\
$68.5 \pm 6.3$ & $145.5 \pm 18.8$ & $4.1 \pm 0.5$ & Term & 12 (white) & 38 \\
\hline
\end{tabular}

\section{Non-pregnant young women}

\begin{tabular}{ccccc}
$48.5 \pm 4.8$ & $4.5 \pm 0.6$ & 10 (black) & 35 \\
$79.5 \pm 5.0$ & $7.8 \pm 0.7$ & 13 (white) & 35 \\
$80.5 \pm 7.8$ & $3.8 \pm 0.8$ & 16 & 36 \\
53.3 & 3.9 & & 39 \\
$35.0 \pm 2.1$ & & 58 & 13 \\
$54.3 \pm 3.1$ & $108.0 \pm 4.4$ & $4.0 \pm 0.4$ & 16 & 40 \\
24.8 & & & 50 & 12 \\
$51.0 \pm 5.0$ & 70.8 & $3.8 \pm 0.4$ & 20 & 28 \\
$48.0 \pm 3.4$ & $104.2 \pm 8.1$ & & 24 & 17 \\
$87.5 \pm 10.5$ & $99.6 \pm 5.6$ & $7.4 \pm 1.0$ & & 29 \\
$46.2 \pm 5.4$ & $89.3 \pm 7.4$ & & 6 & 41 \\
$70.3 \pm 3.6$ & $81.9 \pm 12.1$ & 52 & 42 \\
$51.3 \pm 2.4$ & $76.5 \pm 2.4$ & & 6 & 43 \\
$52.0 \pm 5.1$ & $94.1 \pm 2.4$ & & 14 & 10 \\
\hline
\end{tabular}

$\mathrm{a}=$ Mean \pm SEM. $\mathrm{b}=$ delivered in August-September. $\mathrm{c}=$ delivered in February-March. $\mathrm{d}=$ delivered in March-April. $\mathrm{e}=$ delivered in September-October. $\mathrm{f}=$ women of the first three groups received non specified vitamin $\mathrm{D}$. The women of the last four groups received $\mathrm{D}_{2}$. 
$(48.2 \pm 5.6 \mathrm{nmol} / \mathrm{L}$ vs $51.8 \pm 6.1, \mathrm{p}=0.71)$. In the same groups, the grand mean of serum $1,25(\mathrm{OH})_{2} \mathrm{D}$ was significantly higher in pregnant women than in the controls $(186.7 \pm 13.5 \mathrm{pmol} / \mathrm{L}$ vs $91.4 \pm 4.2, \mathrm{p}<0.0001)$. The ratio $1,25(\mathrm{OH})_{2} \mathrm{D} / 25(\mathrm{OH}) \mathrm{D}$ was calculated by dividing the mean $1,25(\mathrm{OH})_{2} \mathrm{D}$ serum value $(\mathrm{pmol} / \mathrm{L})$ by the mean $25(\mathrm{OH}) \mathrm{D}$ serum value $(\mathrm{nmol} / \mathrm{L})$ in each group. The grand mean of the $1,25(\mathrm{OH})_{2} \mathrm{D} / 25(\mathrm{OH}) \mathrm{D}$ ratio was significantly higher in the pregnant women than in the controls $(4.9 \pm 0.64$ vs $1.96 \pm 0.23, \mathrm{p}=0.006)$. In order to determine whether high serum $1,25(\mathrm{OH})_{2} \mathrm{D}$ represses serum $25(\mathrm{OH}) \mathrm{D}$ during pregnancy, the serum $1,25(\mathrm{OH})_{2} \mathrm{D}$ means were regressed on the serum $25(\mathrm{OH}) \mathrm{D}$ means. There was no significant relationship between $1,25(\mathrm{OH})_{2} \mathrm{D}$ and $25(\mathrm{OH}) \mathrm{D}$ in pregnant women $\left(\mathrm{R}^{2}=0.08, \mathrm{p}=0.22\right)$ or in non-pregnant controls $\left(\mathrm{R}^{2}=0.001, \mathrm{p}=0.93\right)$ (Figure 1$)$. In the majority of the groups of pregnant women at term the means of serum $1,25(\mathrm{OH})_{2} \mathrm{D}$ were found to be between 138 and $242 \mathrm{pmol} / \mathrm{L}$, with the corresponding means of serum 25(OH)D between 15 and $82 \mathrm{nmol} / \mathrm{L}$. In the groups of non-pregnant women the means of serum $1,25(\mathrm{OH})_{2} \mathrm{D}$ were between 71 and $108 \mathrm{pmol} / \mathrm{L}$, with the corresponding means of serum $25(\mathrm{OH}) \mathrm{D}$ between 25 and $88 \mathrm{nmol} / \mathrm{L}$ (Figure 1).

The relationship between $24,25(\mathrm{OH})_{2} \mathrm{D}$ and $25(\mathrm{OH}) \mathrm{D}$ is shown in Figure 2. The serum $25(\mathrm{OH}) \mathrm{D}$ grand mean in the pregnant women ( $\mathrm{n}=13$ means) was significantly lower than the serum $25(\mathrm{OH}) \mathrm{D}$ grand mean $(\mathrm{n}=7$ means) in the controls $(48.5 \pm 4.1 \mathrm{nmol} / \mathrm{L}$ vs $64.9 \pm 6.3, p=0.036)$. In the same groups, the grand means of $24,25(\mathrm{OH})_{2} \mathrm{D}$ and of the ratio $24,25(\mathrm{OH})_{2} \mathrm{D} /$ $25(\mathrm{OH}) \mathrm{D}$ were not different between pregnant and non-pregnant women $(3.9 \pm 0.4 \mathrm{nmol} / \mathrm{L}$ vs $5.0 \pm 0.7$, $\mathrm{p}=0.60)$ and $(0.081 \pm \mathrm{vs} 0.076, \mathrm{p}=0.12)$, respectively. Linear regression of the serum $24,25(\mathrm{OH})_{2} \mathrm{D}$ means on the serum $25(\mathrm{OH}) \mathrm{D}$ means showed significant positive relationship between the two metabolites in the pregnant women $\left(\mathrm{R}^{2}=0.42, \mathrm{p}=0.016\right)$, and almost significant relationship between the two metabolites in the controls $\left(\mathrm{R}^{2}=0.49, \mathrm{p}=0.08\right)$. The slope of the two regression lines was identical and, in fact, the two lines were virtually superimposed (Figure2).

\section{DISCUSSION}

High $1,25(\mathrm{OH})_{2} \mathrm{D}$ serum levels after administration of $1,25(\mathrm{OH})_{2} \mathrm{D}$ in rats $^{19,20}$ or in humans ${ }^{22}$ have been shown to cause a reduction in the serum level of $25(\mathrm{OH}) \mathrm{D}$ by increasing its metabolic clearance rate $^{19}$ or reducing its $t^{1} / 2 .{ }^{24}$ Increased catabolism of $25(\mathrm{OH}) \mathrm{D}$ was demonstrated after inducing high levels of endogenous $1,25(\mathrm{OH})_{2} \mathrm{D}$ by low calcium diet in rats. ${ }^{21}$ Clements et $\mathrm{al}^{24}$ studied patients with various disorders of bone and mineral metabolism and demonstrated that raising serum $1,25(\mathrm{OH})_{2} \mathrm{D}$ reduces the elimination half-time of $25(\mathrm{OH}) \mathrm{D}$ in serum, which means that high $1,25(\mathrm{OH})_{2} \mathrm{D}$ accelerates the catabolism of $25(\mathrm{OH}) \mathrm{D}$. The findings of Davies ${ }^{23}$ were similar in patients with partial gastrectomy and secondary hyperparathyroidism with high $1,25(\mathrm{OH})_{2} \mathrm{D}$ serum levels.


Figure 1. Comparison of the grand means $( \pm \mathrm{SEM})$ of serum $25(\mathrm{OH}) \mathrm{D}(\mathrm{nmol} / \mathrm{L})$, serum $1,25(\mathrm{OH})_{2} \mathrm{D}(\mathrm{pmol} / \mathrm{L})$, and of the $\mathrm{ra}-$ tio $1,25(\mathrm{OH})_{2} \mathrm{D} / 25(\mathrm{OH}) \mathrm{D}$ between pregnant $(\mathrm{n}=20)$ and non-pregnant $(\mathrm{n}=9)$ young women $(\mathrm{A})$. Linear regression of the serum $1,25(\mathrm{OH})_{2} \mathrm{D}$ means on the serum $25(\mathrm{OH}) \mathrm{D}$ means in pregnant $(\mathrm{n}=20)$ and non-pregnant women $(\mathrm{n}=9)(\mathrm{B})$. NS=Non significant. 

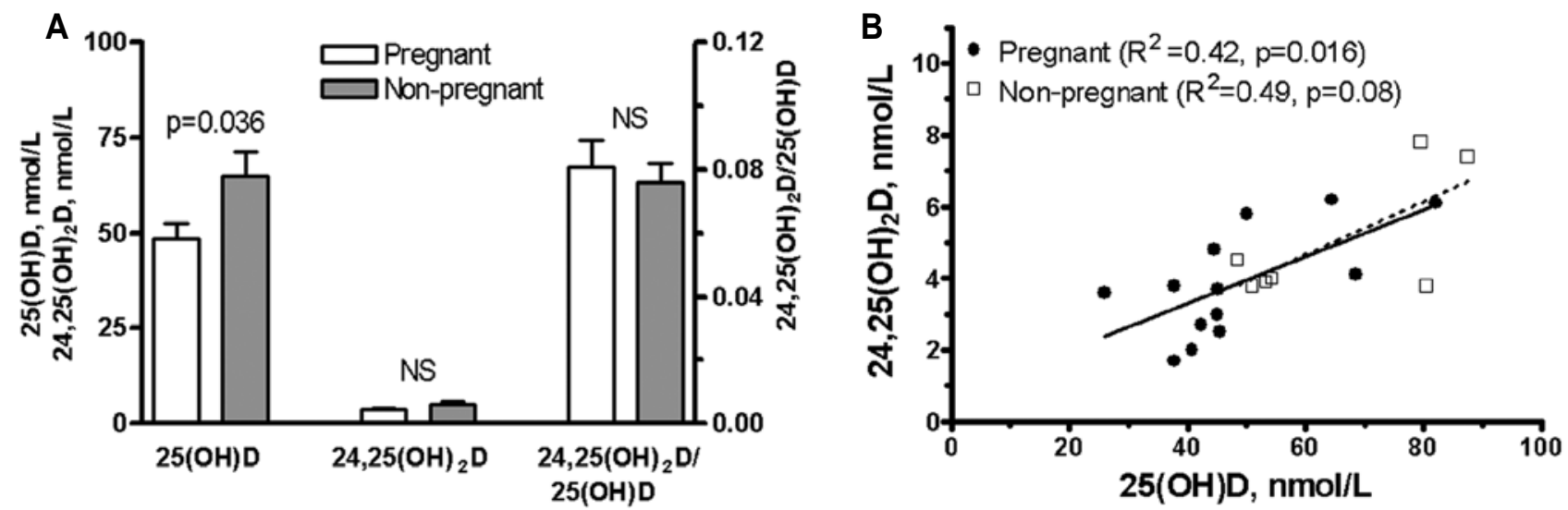

Figure 2. Comparison of the grand means ( \pm SEM) of serum $25(\mathrm{OH}) \mathrm{D}$, serum $24,25(\mathrm{OH})_{2} \mathrm{D}$, and of the ratio $24,25(\mathrm{OH})_{2} \mathrm{D} / 25(\mathrm{OH}) \mathrm{D}$ between pregnant $(n=13)$ and non-pregnant $(n=7)$ young women $(A)$. Linear regression of the serum $24,25(\mathrm{OH})_{2} \mathrm{D}$ means on the serum 25(OH)D means in pregnant $(\mathrm{n}=13)$ and non-pregnant women $(\mathrm{n}=7)(\mathrm{B}) . \mathrm{NS}=$ Non significant.

One of the objectives of this meta-analysis was to investigate if the same effect of high $1,25(\mathrm{OH})_{2} \mathrm{D}$ serum levels upon serum $25(\mathrm{OH}) \mathrm{D}$ occurs in human pregnancy. In the 20 groups of pregnant and 9 groups of non-pregnant women, both mean serum $25(\mathrm{OH}) \mathrm{D}$ and mean serum $1,25(\mathrm{OH})_{2} \mathrm{D}$ were available for analysis. While the grand mean (mean of the means of each group) of serum $25(\mathrm{OH}) \mathrm{D}$ in pregnant women was not statistically different from the grand mean in non-pregnant women, the grand mean of serum $1,25(\mathrm{OH})_{2} \mathrm{D}$ in pregnant women was twice as high when compared to the grand mean of non-pregmant women. The grand mean of the $1,25(\mathrm{OH})_{2} \mathrm{D} / 25(\mathrm{OH}) \mathrm{D}$ ratio was approximately 2.5 times higher in pregnant women when compared to non-pregnant women. These data, taken together, imply that in pregnant women at term a frankly high level of serum $1,25(\mathrm{OH})_{2} \mathrm{D}$ is maintained in comparison to non-pregnant women despite nondifferent 25(OH)D serum levels (Figure 1). It is not possible from the data analyzed here to determine if the high serum level of $1,25(\mathrm{OH})_{2} \mathrm{D}$ is exclusively due to increased binding of the hormone to DBP or also to a concomitant increase of free $1,25(\mathrm{OH})_{2} \mathrm{D}$. Regression of the means of serum $1,25(\mathrm{OH})_{2} \mathrm{D}$ on the means of serum $25(\mathrm{OH}) \mathrm{D}$ showed no significant relationship between the two metabolites in pregnant women. This finding militates against a possible repressing effect of high serum $1,25(\mathrm{OH})_{2} \mathrm{D}$ on serum $25(\mathrm{OH}) \mathrm{D}$ in pregnancy. Also, in favor of this opinion is the fact that serum $25(\mathrm{OH}) \mathrm{D}$ does not seem to rise after delivery when serum $1,25(\mathrm{OH})_{2} \mathrm{D}$ falls abruptly. ${ }^{9,10}$ No significant relationship was also found between the means of serum $1,25(\mathrm{OH})_{2} \mathrm{D}$ and the means of serum $25(\mathrm{OH}) \mathrm{D}$ in the young non-pregnant women. This finding differs from that of Rejnmark et $\mathrm{al}^{7}$ in postmenopausal women and raises the question whether the relationship between serum $1,25(\mathrm{OH})_{2} \mathrm{D}$ and serum 25(OH)D may be age dependent.

High serum $1,25(\mathrm{OH})_{2} \mathrm{D}$ also induced a fall in serum $24,25(\mathrm{OH})_{2} \mathrm{D}$ in rats, in parallel with the fall in serum $25(\mathrm{OH}) \mathrm{D} .{ }^{19}$ In patients with partial gastrectomy and high serum $1,25(\mathrm{OH})_{2} \mathrm{D}$, serum $24,25(\mathrm{OH})_{2} \mathrm{D}$ was found to be significantly lower than in controls..$^{44}$ In the 13 groups of pregnant and 7 groups of non-pregnant women, both mean serum $25(\mathrm{OH}) \mathrm{D}$ and mean serum $24,25(\mathrm{OH})_{2} \mathrm{D}$ were available for analysis. The grand mean of serum $25(\mathrm{OH}) \mathrm{D}$ was significantly lower in pregnant than in control women. The grand mean of serum $24,25(\mathrm{OH})_{2} \mathrm{D}$ was also lower in the pregnant women, although not significantly. However, the grand means of the $24,25(\mathrm{OH})_{2} \mathrm{D} / 25(\mathrm{OH}) \mathrm{D}$ ratio in pregnant and control women were not different (Figure 2). Regression of the means of serum $24,25(\mathrm{OH})_{2} \mathrm{D}$ on the means of serum $25(\mathrm{OH}) \mathrm{D}$ showed a significant relationship between the two vitamin $\mathrm{D}$ metabolites in pregnant women and almost significant relationship in the controls. The regression coefficients indicated that $42 \%$ of the variation of the means of serum $24,25(\mathrm{OH})_{2} \mathrm{D}$ could be explained by changes in the means of serum $25(\mathrm{OH}) \mathrm{D}$ in pregnant women, and $49 \%$ of the vari- 
ation of the means of serum $24,25(\mathrm{OH})_{2} \mathrm{D}$ could be explained by changes in the means of serum $25(\mathrm{OH}) \mathrm{D}$ in non-pregnant women (Figure 2). These data imply that very likely the metabolism of $24,25(\mathrm{OH})_{2} \mathrm{D}$ is not different in pregnant and non-pregnant women.

The substrate for the biosynthesis of both $1,25(\mathrm{OH})_{2} \mathrm{D}$ and $24,25(\mathrm{OH})_{2} \mathrm{D}$ is $25(\mathrm{OH}) \mathrm{D} .{ }^{1}$ This meta-analysis showed that serum $1,25(\mathrm{OH})_{2} \mathrm{D}$ is not related to serum $25(\mathrm{OH}) \mathrm{D}$, whereas by contrast serum $24,25(\mathrm{OH})_{2} \mathrm{D}$ is significantly related to serum $25(\mathrm{OH}) \mathrm{D}$ in both pregnant and non-pregnant young women. These findings allow the conclusion that in human pregnancy the high serum levels of $1,25(\mathrm{OH})_{2} \mathrm{D}$ do not seem to induce changes in the metabolism of $24,25(\mathrm{OH})_{2} \mathrm{D}$, while for a possible effect of high $1,25(\mathrm{OH})_{2} \mathrm{D}$ on $25(\mathrm{OH}) \mathrm{D}$ a similar conclusion is less clear. The best method to resolve this matter is probably the measurement of the elimination half-time of serum $25(\mathrm{OH}) \mathrm{D}$ in pregnant women, using the method employed by Clements et $\mathrm{al}^{20,24}$

In the majority of the studies analyzed here, mean serum $1,25(\mathrm{OH})_{2} \mathrm{D}$ in pregnant women was high $(>138$ $\mathrm{pmol} / \mathrm{L})$, while mean serum $25(\mathrm{OH}) \mathrm{D}$ was less than $50 \mathrm{nmol} / \mathrm{L}$, and in three studies less than $25 \mathrm{nmol} / \mathrm{L}$. Only in one study ${ }^{30}$ did pregnant women with severe vitamin D deficiency [extremely low $25(\mathrm{OH}) \mathrm{D}$ ] have relatively low serum $1,25(\mathrm{OH})_{2} \mathrm{D}$. Consequently, it seems uncertain whether many pregnant women with low serum $25(\mathrm{OH}) \mathrm{D}$ but high serum $1,25(\mathrm{OH})_{2} \mathrm{D}$ may be characterized as vitamin $\mathrm{D}$ deficient. On the other hand, among the studies herein analyzed, only in one study ${ }^{34}$ was mean serum 25(OH)D above 80 $\mathrm{nmol} / \mathrm{L}$ and in this case mean serum $1,25(\mathrm{OH})_{2} \mathrm{D}$ was not unusually high for pregnant women (see Table 1 and Figure 1). Therefore, it is not possible from these data to predict $1,25(\mathrm{OH})_{2} \mathrm{D}$ serum levels when $25(\mathrm{OH}) \mathrm{D}$ serum levels are frankly above $80 \mathrm{nmol} / \mathrm{L}$ during pregnancy.

Among the limitations of this meta-analysis are the limited number of the analyzed studies, the heterogeneity of the studied populations, and the variable methods used for the measurements of the vitamin D metabolites.

Possible mechanisms responsible for the high serum $1,25(\mathrm{OH})_{2} \mathrm{D}$ in pregnancy have been proposed (see review by Kovacs). ${ }^{16}$ Theoretically, super-stimulation of renal 1- $\alpha$-hydroxylase ${ }^{1}$ by an undefined mechanism can result in extremely high circulating $1,25(\mathrm{OH})_{2} \mathrm{D}$ in the pregnant woman. Another possibility, not excluding the previous one, is increased availability of $25(\mathrm{OH}) \mathrm{D}$ to the maternal renal 1- $\alpha$-hydroxylase for activation. How can this be accomplished even in cases with relatively low levels of $25(\mathrm{OH}) \mathrm{D}$ in the maternal circulation? A major pathway by which $25(\mathrm{OH}) \mathrm{D}$ can enter the epithelial cells of the proximal renal tubules for activation is through their luminal site. Nykjaer et $\mathrm{a}^{45}$ have demonstrated that the filtered DBP-25(OH)D complex is taken up from the glomerular filtrate by the epithelial cells of the proximal renal tubules through endocytic megalin-cubilin coreceptors. Glomerular filtration rate is increased in pregnant women and this may theoretically result in increased filtered load of DBP-25(OH)D and increased uptake of the complex by the renal tubular epithelium. The existence of this pathway implies that the free hormone hypothesis is not essential to explain the uptake of $25(\mathrm{OH}) \mathrm{D}$ or $1,25(\mathrm{OH})_{2} \mathrm{D}$ by cells of various tissues having megalin receptors. ${ }^{45}$

In two longitudinal studies, ${ }^{10,46}$ the true percentage of calcium absorption was found to be higher in pregnant women with low $^{46}$ compared to pregnant women with high calcium intake. ${ }^{10}$ Then again, urinary excretion of calcium increased during pregnancy in women with high calcium intake ${ }^{10}$ but decreased in women with low calcium intake. ${ }^{46}$ Therefore, it seems that calcium homeostasis can adapt to low calcium intake during pregnancy ${ }^{46}$ The mechanism for this adaptation is not understood, and the role of the high $1,25(\mathrm{OH})_{2} \mathrm{D}$ serum levels in the increased intestinal absorption of calcium during pregnancy has not been determined. ${ }^{16,46}$ Many hormones such as PTH, estrogens, prolactin, and human placental lactogen may apparently be involved in the regulation of calcium homeostasis in pregnancy, while it has been suggested that vitamin $\mathrm{D}$ does not have an important role in the increased intestinal calcium absorption during pregnancy. ${ }^{16}$ The possibility that the hypercortisolism of pregnancy ${ }^{47}$ may be a cause of some degree of vitamin D resistance and the effects on calcium homeostasis of the chronic respiratory alkalosis ${ }^{48}$ commonly affecting pregnant women should also be considered.

In conclusion, it is not clear whether vitamin 
D deficiency [low 25(OH)D serum levels] is more frequent in pregnant women when compared to age matched non-pregnant women. This may be very difficult to determine since vitamin D status depends on a multitude of environmental factors. It could be argued that pregnant women may be characterized as having hypervitaminosis $\mathrm{D}$ because of their frankly elevated $1,25(\mathrm{OH})_{2} \mathrm{D}$ serum concentration. This meta-analysis demonstrated that the elevated serum $1,25(\mathrm{OH})_{2} \mathrm{D}$ during pregnancy is not related to serum $25(\mathrm{OH}) \mathrm{D}$. It also showed that, very likely, the high serum $1,25(\mathrm{OH})_{2} \mathrm{D}$ in pregnancy does not repress the serum $25(\mathrm{OH}) \mathrm{D}$ levels as was demonstrated in studies in animals and non-pregnant humans. Paraphrasing Kovacs ${ }^{16}{ }^{16}$ we consider that there is need for prospective studies with large numbers of pregnant women to elucidate whether the same criteria established for the definition of vitamin status in the non-pregnant adults can also be applied to pregnant women.

\section{REFERENCES}

1. Plum LA, DeLuca HF, 2009 The functional metabolism and molecular biology of vitamin D action. Clinic Rev Bone Miner Metab 7: 20-21.

2. Malabanan A, Veronikis IE, Holick MF, 1998 Redefining vitamin D insufficiency. Lancet 351: 805-806.

3. Chapuy MC, Preziosi P, Maamer M, et al, 1997 Prevalence of vitamin D insufficiency in an adult normal population. Osteoporos Int 7: 439-444.

4. Papapetrou PD, Triantaphyllopoulou M, Karga H, et al, 2007 Vitamin D deficiency in the elderly in Athens, Greece. J Bone Miner Metab 25: 198-203.

5. Heaney RP, 2004 Functional indices of vitamin D status and ramifications of vitamin D deficiency. Am J Clin Nutr 80: Suppl 6:1706-1709.

6. Bischoff-Ferrari HA, Willett WC, Wong JB, Giovannucci E, Dietrich T, Dawson-Hughes B, 2005 Fracture prevention with vitamin $\mathrm{D}$ supplementation: a metaanalysis of randomized controlled trials. JAMA 293: 2257-2264.

7. Rejnmark L, Vestergaard P, Heickendorff L, Mosekilde L, 2008 Plasma $1,25(\mathrm{OH})_{2} \mathrm{D}$ levels decrease in postmenopausal women with hypovitaminosis D. Eur J Endocrinol 158: 571-576.

8. Seki K, Makimura N, Mitsui C, Jirata J, Nagata I, 1991 Calcium-regulating hormones and osteocalcin levels during pregnancy: a longitudinal study. Am J Obstetr Gynecol 164: 1248-1252.

9. Ardawi MSM, Nasrat HAN, BA'Aqueel HS, 1997 Calcium-regulating hormones and parathyroid hormone-related peptide in normal human pregnancy and postpartum: a longitudinal study. Eur J Endocrinol 137: 402-409.

10. Ritchie LD, Fung EB, Halloran BP, et al, 1998 A longitudinal study of calcium homeostasis during human pregnancy and lactation and after resumption of menses. Am J Clin Nutr 67: 693-701.

11. Uemura H,Yasui T, Kiyokawa M, et al, 2002 Serum osteoprotegerin/osteogenesis-inhibitory factor during pregnancy and lactation and the relationship with calcium-regulating hormones and bone turnover markers. J Endocrinol 174: 353-359.

12. Whitehead M, Lane G, Young O, et al, 1981 Interrelations of calcium-regulating hormones during normal pregnancy. Br Med J (Clin Res Ed) 283: 10-12.

13. Bouillon R, Van Assche FA, Van Baelen H, Heyns W, De Moor P, 1981 Influence of the vitamin D-binding protein on the serum concentration of 1,25-dihydroxyvitamin D3. Significance of the free 1,25-dihydroxyvitamin D3 concentration. J Clin Invest 67: 589-596.

14. Kuoppala T, Tuimala R, Parviainen M, Koskinen T, Ala-Houhala M, 1986 Serum levels of vitamin D metabolites,calcium, phosphorus, magnesium and alkaline phosphatase in Finnish women throughout pregnancy and in cord serum at delivery. Hum Nutr Clin Nutr 40: 287-293.

15. Zehnder D, Evans KN, Kilby MD, et al, 2002 The ontogeny of 25-hydroxyvitamin $\mathrm{D}_{3} 1 \alpha$-hydroxylase expression in human placenta and decidua. Am J Pathol 161: $105-114$

16. Kovacs CS, 2008 Vitamin D in pregnancy and lactation: maternal, fetal, and neonatal outcomes from human and animal studies. Am J Clin Nutr 88: Suppl: 520-528.

17. Bikle DD, Gee E, Halloran B, Haddad JG, 1984 Free 1,25-dihydroxyvitamin D levels in serum from normal subjects, pregnant subjects, and subjects with liver disease. J Clin Invest 74: 1966-1971.

18. van Hoof HJC, de Sévaux RGL, van Baelen H, et al, 2001 Relationship between free total 1,25-dihydroxyvitamin $\mathrm{D}$ in conditions of modified binding. Eur J Endocrinol 144: 391-396.

19. Halloran BP, Castro ME, 1989 Vitamin D kinetics in vivo: effect of 1,25-dihydroxyvitamin $\mathrm{D}$ administration. Am J Physiol 256: E686-E691.

20. Berlin T, Björkhem I, 1987 On the regulatory importance of 1,25-dihydroxyvitamin $\mathrm{D}_{3}$ and dietary calcium on serum levels of 25-hydroxyvitamin $\mathrm{D}_{3}$ in rats. Biochem Biophys Res Commun 144: 1055-1058.

21. Clements MR, Johnson L, Fraser DR, 1987 A new mechanism for induced vitamin $\mathrm{D}$ deficiency in calcium deprivation. Nature 325: 62-65.

22. Loré F, Di Cairano G, Periti P, Caniggia A, 1982 Effect of the administration of 1,25-dihydroxyvitamin $\mathrm{D}_{3}$ on serum levels of 25-hydroxyvitamin D in postmenopausal women. Calcif Tissue Int 34: 539-541.

23. Davies M, Heys SE, Selby PL, Berry JL, Mawer EB, 1997 Increased catabolism of 25-hydroxyvitamin D in 
patients with partial gastrectomy and elevated 1,25dihydroxyvitamin D levels. Implications for metabolic bone disease. J Clin Endocrinol Metab 82: 209-212.

24. Clements MR, Davies M, Hayes ME, et al, 1992 The role of 1,25-dihydroxyvitamin $\mathrm{D}$ in the mechanism of acquired vitamin D deficiency. Clin Endocrinol 37: 17-27.

25. Fleischman AR, Rosen JF, Cole J, Smith CM, DeLuca HF, 1980 Maternal and fetal serum 1,25-dihydroxyvitamin D levels at term. J Pediatr 97: 640-642.

26. Gertner JM, Glassman MS, Coustan DR, 1980 Goodman BP. Fetomaternal vitamin D relationships at term. J Pediatr 97: 637-640.

27. Delvin EE, Glorieux FH, Salle BL, David L, Varenne JP, 1982 Control of vitamin D metabolism in preterm infants: feto-maternal relationships. Arch Dis Child 57: 754-757.

28. Seino Y, Ishida M, Yamaoka K, et al, 1982 Serum calcium regulating hormones in the perinatal period. Calcif Tissue Int 34: 131-135.

29. Shany S, Biale Y, Zuili I, Yankowitz N, Berry JL, Mawer EB, 1984 Feto-maternal relationships between vitamin $\mathrm{D}$ metabolites in Israeli Bedouins and Jews. Am J Clin Nutr 40: 1290-1294.

30. Mallet E, Gugi B, Brunelle P, Henocq A, Basuyau JP, Lemeur H, 1986 Vitamin D supplementation in pregnancy: a controlled trial of two methods. Obstet Gynecol 68: 300-304.

31. Ron M, Menczel J, Schwartz L, Palti Z, Kidroni G, 1987 Vitamin D3 metabolites in amniotic fluid in relation with maternal and fetal sera in term pregnancies. J Perinat Med 15: 282-290.

32. Nehama H, Wientroub S, Eisenberg Z, Birger A, Milbauer B, Weisman Y, 1987 Seasonal variation in paired maternal-newborn serum 25-hydroxyvitamin D and 24,25-dihydroxyvitamin D concentrations in Israel. Isr J Med Sci 23: 274-277.

33. Brunvand L, Haug E, 1993 Vitamin D deficiency amongst Pakistani women in Oslo. Acta Obstet Gynecol Scand 72: 264-268.

34. Seely EW, Brown EM, DeMaggio DM, Weldon DK, Graves SW, 1997 A prospective study of calciotropic hormones in pregnancy and post partum: reciprocal changes in serum intact parathyroid hormone and 1,25dihydroxyvitamin D. Am J Obstet Gynecol 176: 214217.

35. Weisman Y, Occhipinti M, Knox G, Reiter E, Root A, 1978 Concentrations of 24,25-dihydroxyvitamin D and 25-hydroxyvitamin D in paired maternal-cord sera. Amer J Obstet Gynecol 130: 704-707.

36. Reiter EO, Braunstein GD, Vargas A, Root AW, 1979 Changes in 25-hydroxyvitamin D and 24,25-dihydroxyvitamin D during pregnancy. Am J Obstet Gynecol 135: 227-229.

37. Markestad T, Aksnes L, Ulstein M, Aarskog D, 1984 25-Hydroxyvitamin D and 1,25-dihydroxyvitamin D of
D2 and D3 origin in maternal and umbilical cord serum after vitamin D2 supplementation in human pregnancy. Am J Clin Nutr 40: 1057-1063.

38. Hollis BW, Pittard WB $3^{\text {rd }}$, 1984 Evaluation of the total fetomaternal vitamin D relationships at term: evidence for racial differences. J Clin Endocrinol Metab 59: 652657.

39. Kano K, Yoshida H, Yata J, Suda T, 1980 Age and seasonal variations in the serum levels of 25-hydroxyvitamin D and 24,25-dihydroxyvitamin D in normal humans. Endocrinol Jpn 27: 215-221.

40. Parviainen MT, Savolainen KE, Alhava EM, Mäenpää PH, 1981 5-hydroxyvitamin D2, 25-hydroxyvitamin D3 and total 24,25-dihydroxyvitamin D in human serum. Ann Clin Res 13: 26-33.

41. Van Der Klis FR, Jonxis JH, Van Doormaal JJ, Sikkens P, Saleh AE, Muskiet FA, 1996 Changes in vitamin$\mathrm{D}$ metabolites and parathyroid hormone in plasma following cholecalciferol administration to pre- and postmenopausal women in the Netherlands in early spring and to postmenopausal women in Curanao. $\mathrm{Br}$ J Nutr 75: 637-646.

42. Kinyamu HK, Gallagher JC, Balhorn KE, Petranick KM, Rafferty KA, 1997 Serum vitamin D metabolites and calcium absorption in normal young and elderly free-living women and in women living in nursing homes Am J Clin Nutr 65:790-797. Erratum in: Am J Clin Nutr 66: 454

43. Levis S, Gomez A, Jimenez C, et al, 2005 Vitamin D deficiency and seasonal variation in an adult South Florida population. J Clin Endocrinol Metab 90: 15571562.

44. Klein KB, Orwoll ES, Lieberman DA, Meier DE, McClung MR, Parfitt AM, 1987 Metabolic bone disease in asymptomatic men after partial gastrectomy with Billroth II anastomosis. Gastroenterology 92: 608-616.

45. Nykjaer A, Fyfe JC, Kozyraki R, et al, 2001 Cubilin dysfunction causes abnormal metabolism of the steroid hormone $25(\mathrm{OH})$ vitamin $\mathrm{D}_{3}$. Proc Natl Acad Sci USA 98: 13895-13900.

46. Zapata CLV, Domangelo CM, Woodhouse LR, Abrams SA, Spencer EM, King JC, 2004 Calcium homeostasis during pregnancy and lactation in Brazilian women with low calcium intakes: a longitudinal study. Am J Clin Nutr 80: 417-422.

47. Clerico A, Del Chicca MG, Ferdeghini M, Ghione S, Materazzi F, 1980 Progressively elevated levels of biologically active (free) cortisol during pregnancy by a direct radioimmunological assay of diffusible cortisol in an equilibrium dialysis system. J Endocrinol Invest 3: $185-187$.

48. Krapf R, Jaeger P, Hulter HN, 1992 Chronic respiratory alkalosis induces renal PTH-resistance, hyperphosphatemia and hypocalcemia in humans. Kidney Int 42: $727-734$. 